\title{
Relationship Between Some Traits Used As Mastitis Indicators in Holstein Cows' Milk
}

\author{
Muhammed Ikbal YESIL ${ }^{*} \quad$ Serap GONCU \\ Animal Science, Cukurova University 01330, Saricam Adana, Turkey
}

\begin{abstract}
This study was carried out in order to identify the relations between Somatic cell count (SCC), milk temperature, milk pH and milk density in mastitic and non-mastitic Holstein Friesian cows. The animal material of the study was mastitic and non-mastitic Black and White cows which similar age and lactation number. At the end of the study, it was defined that the mastitic milk was highly corelated with SCC and $\mathrm{pH}$ of milk $(\mathrm{r}=0,633 ; \mathrm{r}=0,570$ respectively). While in healthy group (non-mastitic), there wasn't any correlation between the SCC and the other parameters; but in the mastitic group, it was found that there was significant correlations statistically between SCC and other parameters.
\end{abstract}

Keywords: SCC, cows, Milk temperature, $\mathrm{pH}$, electrical conductivty, density

DOI: $10.7176 /$ ISDE/11-1-03

Publication date: January $31^{\text {st }} 2020$

\section{Introduction}

In todays dairy industries, $\% 90$ of total milk production is cattle milk (TÜIK, 2016). In Turkey, average daily milk production per animal is about to $20 \mathrm{~kg}$. For production of 20 liters of milk, considering 500 liters of blood circulates in udder for a liter milk production, 10.000 liters of blood circulates in udder daily. (Gradinaru, Creanga and Solcan, 2015) This creates a great physiological strain on the animal. Animals under such a strain environment are more sensitive to environmental factors. Perhaps the most important of these factors are microorganisms that cause to mastitis.

Mastitis is a febrile and inflamative infectious udder disease that can be seen all mammalian. Mastitis can be divided into two classes: clinical and subclinical mastitis. Clinical mastitis can be seen visually (Atasever and Erdem 2008). It is easy to diagnose. There is no visual symptom to determine subclinical mastitis (Harmon, 1994) but it can be determined by just analyzing milk. Therefore it is known as latent mastitis or milk thief. The most important symptoms of mastitis are decrease of milk yield, inflamation in udder, decrese of milk quality, even udder loss and death.

In dairy farming, it is unknown that which animal is infected by mastitis disease. And it is recommended to cure all animals at the end of lactation (Maatje et al., 1991).

It is known that the decrease in milk yield can up to \%10 in mastitis cows during lactation, even it can vary between 350-750 kg per cow during a year. (Hortet and Seegers, 1998) The determination of subclinical mastitis in cows can be understood by analyzing milk structure factors. These factors in milk structure are somatic cell count (SCC), electrical conductivity (EC), $\mathrm{pH}$, density and milk temperature and changes of fat and proteins contents.

The bacterias that cause mastitis can be categorized as major and minor pathogens (Harmon, 1994). The most common major pathogens are Staphylococcus aureus, Streptococcus agalacriae, coliforms, streptococcus and environmetal based enterococcus. Pseudomonas spp., Actinomyces pyogenes, Serratia spp., or the others pathogens, can cause individual mastitis cases and rarely epidemic disease. Major pathogens are microorganizms that cause the largest compositional changes in milk, including increases in SCC, which causes the most economic losses. On the oher hand Coagulase-negative staphylococci and Corynebacterium are accepted as minor pathogens. Minor pathogens rarely cause clinical mastitis, decompositon of milk or decrease in yield of milk. The infections that these organisms caused, cause weak inflammation in mammary glands with 2-3 fold in SCC (Harmon, 1994).

Göncü et al. (2002), indicates that Barkema et al. (1999a), the incidence of mastitis and major factors in, reported that the major effects that affect mastitis are housing, hygiene and machine milking, feding and milking techniques. Also, Barkema et al. (1999b), divide cultivators into subgroups and investigate the relationship between the work done by farmers and the incidence of mastitis. They reported that the correlation between SCC values of milk tank as a result of analysis is strong but the relationship with clinical mastitis is weak. Managers of farms with low tank milk SCC were found to be younger, have higher family education levels and are more likely to invest in farming, better kept herd records and better acquainted with cows individually when compared to farm managers with high SCC. They also stated that barn features such as the herd size of the herd, the settlement of the barn, the type of ground and the milking practices in the field can be listed as other factors that are also effective in issues (Barkema et al., 1999a).

Nielen et al. (1992), report that in a study that electrical conductivity of milk: the performance of mastitis detection and meta-analyzes, the intensity of released ions increases the permeability of blood vessels and impairs 
the functioning of the active ion transport system. Thus, the EC values in the milk are also increasing due to increase of $\mathrm{Na}$ and $\mathrm{Cl}$ ions in milk. Electrical conductivity (EC) are influenced by mastitis, in addition factors such as breed, lactation period, milking interval, composition of milk, daily changes, lactation number, oestrus, diseases, nutritional level, udder lobes and management factors.

Mol et al. (2000), stated that mastitis can be diagnosed based on such things as electrical conductivity, milk temperature and milk yield.

In a study that compared indirect methods used to diagnose subclinical mastitis, researchers reported that lactose and potassium $(\mathrm{K})$ move out of the extracellular fluid, while sodium $(\mathrm{Na})$ and chlorine $(\mathrm{Cl})$ move into the milk to maintain osmotic pressure in the epithelial cells. (Špauskas et al., 2006).

Gil et al. (1988), reported that the quarter that infected by subclinical mastitis has a high correlation with the electrical conductivity and chloride content of the deviation of milk temperature during milking. In addition, Gil et al noted that temperature fluctuations in the milk from mastitic mammals are also very clear.

Fernando et al. (1985), also found that electrical conductivity is a very sensitive indicator of mastitis, while at the same time there is a high degree of correlations between conductivity and chloride content.

Suranindyah et al. (2015), reported that improving the hygiene conditions significantly reduced the number of bacteria in the milk and increased the density of milk and fat-free dry matter in a study conducted on 23 cows with milk quality effect on improving hygiene conditions during milking in Indonesia.

Harmon (1994), in his study on mastitis physiology and factors affecting SCC; the $\mathrm{pH}$ values of the milk may increase from 6.6 to 6.9 or even higher due to the increased $\mathrm{pH}$ of the enzyme and the $\mathrm{pH}$ of the blood mixed with the diseased tissue (mastitis etc.).

This study was carried out in order to identify the relations between Somatic cell count (SCC), milk temperature, milk $\mathrm{pH}$ and milk density in mastitic and non-mastitic Black and White cows.

\section{Materials And Methods}

The animal material of this study was black and white cows in the Cukurova University Research Application Farm in Adana Turkey. There is a 10x2 automated milking system in enterprise.

\subsection{Milk Sampling}

Milk samples were taken daily from November 2017 to April 2018 from cows which with or without a sign of clinical mastitis with similar ages, lactation and lactation periods during cure. Before starting milking the cows with automated milking system, milk that accumulated in quarters were taken into milking cups. After that milk samples were taken into $250 \mathrm{ml}$ sample tubes. During operation maximum attention has been paid to keeping hygenie rules. After CMT was performed, SCC, EC, initial milk temperature, $\mathrm{pH}$ and density of milk were measured.

Microorganisms contamination is prevented by applying disenfectant solution to the udder.

Milk samples are transported to the Cukurova University Agricultural Faculty Cattle Livestock Laboratory in a cold chain to analyze SCC and milk density.

Measurements are labelled according to cow number, sample number, status (mastitis / healthy), milk sample (initial milk / last milk) and quarter that samples taken

Somatic cell counts higher than $200,000 / \mathrm{ml}$ on the basis of quarter were accepted as suspicious of subclinical mastitis, while lower than 200,000/ $\mathrm{ml}$ were considered healthy (non-mastitic). SCC is indicator of latent mastitis. Also SCC is indicator of lack of herd management, milking and hygenie mistakes, protective medicine negligence (Göncü and Özkütük, 1999; Göncü, 2017).

EC and temperature of mastitic or non-mastitic milks was measured via Adwa AD43 TDS meter, SCC via Delaval DCC somatic cell counter, ph of the milk via AZ 86505 pH meter and density of milk via densimeter (pycnometer). This devices works base on immersion to the milk. The probes of this device immerse to the sample and measurement is recorded if stability indicator seen on screen.

\subsection{SCC Measurement}

In this study, milk somatic cell number was determined by using Delaval DCC somatic cell counting device, which measures the number of somatic cells on the basis of DNA specific fluorescent somatic cell nuclei. Milk samples were taken twice daily, morning and evening, once a week, preheated at $+40^{\circ} \mathrm{C}$, then mixed gently. In milk samples preliminary somatic cell count (Cell Count, Delaval, Sweden) was performed. Changes related to somatic cell numbers of a cow are developed for testing.

For accurate SCC with Delaval DCC cell counter cassette which has to be avoided for contamination is immersed to the milk sample and the pistol is pushed down. After taking milk into the cassette, it is placed into cassete section. The cover of cassette section is closed and the Run button on the device is pushed down. In approximately 40 seconds, the result is displayed on the device screen and the recordings are taken. Somatic cell count measurements with Delaval. 


\subsection{Measurement of Milk pH}

AZ86505 $\mathrm{pH}$ meter was used to measure the milk $\mathrm{pH}$. The probe of device is immersed into the sample tube with milk and recording are taken when stability indicator seen on screen.

\subsection{Measurements of Electrical Conductivity and Temperature}

To measure EC and Temperature of milk with Adwa AD-32 TDS meter, probe is immersed in milk sample. After stability indicator appears on the screen, results are recorded.

The milk sample is filled into a $250 \mathrm{ml}$ densimeter tube. Then the densimeter is immersed in the tube filled with milk. When the densimeter is stabilized in the liquid, the value at the intersection of densimeter and the milk is read from the densimeter and the result is recorded.

\subsection{Statistical Analyzes}

Homogeneity test is applied to datas before any analyzes and it was determined that parameters of healthy group is not show normal distribution except temperature while in mastitic group only SCC is not show normal distribution. Logarithmic transformation is applied to the non-normal distributive SCC's data and analyzes was carried out (Kayaalp, 2017; Kayaalp, 2013).

Test of homogeneity is applied to data that obtained before any analyze and it was determined that SCC is not show normal distribution. Logarithmic transformation is applied to the non-normal distributive SCC's data and analyzes was carried out (Kayaalp, 2017; Kayaalp, 2013).

Shook et al. (1980), in a study conducted on an optimum transformation for somatic cell concentration in milk; report that logarithmic transformasyon is the best transformation model among models they have applied on SCC and noted that logarithmic transformation should be used extensively in somatic cell counts analyzes.

Regression analyzes is used to examine how the value of a variable is affected by changes in other variable or variables and how a casual relationships between them is. Correlation analyzes are used to determine whether there is a relationship between two variables and its extent. (Akgül, 2003; Alpar, 2003; Altman, 1992; DawsonSaunders, Trapp, 1990; Draper, Smith, 1981; Kayaalp, 2013). Regression and correlation analyzes are done in SPSS package program to determine relations between SCC, EC, initial milk temperature, density and $\mathrm{pH}$ of the milk.

\section{Results and Discussion}

In this study, regression analyzes are applied to milk samples in order to determine relation between SCC, EC, initial milk temperature, ph and density. And using this relation to estimate or foresee for construction mathematical expressions. Also, after regression analyzes was performed, correlation analyzes applied to determine correlation direct and and extent between variables.

In this part of study, first regression analyzes were perforemed in order to determine how a relationship between parameters is, then correlation analyzes were performed in order to determine correlation direction and extent.

This study was conducted to determine how SCC is related to EC, initial mil temperature, density and ph of the with and without mastitic milk and to develope an alternative method to detect subclinical mastitis.

The mean, minimum and maximum values of SCC, EC, temperature, density and $\mathrm{pH}$ of the milks with and without mastitis are gien in Table 1 .

The mean values of mastitic group are $1066.86 \pm 83.537,7.07 \pm 0.141,1.030 \pm 0.002,33.51 \pm 0.199$, $6.88 \pm 0.026$, respectively while mean values of healthy group respectively are $75.736 \pm 4.875,5.809 \pm 0.055$, $1.032 \pm 0.0003,34.387 \pm 0.13,6.708 \pm 0.012$.

Regression Analyses of Healthy and Mastitic Milks

Linear regression analyzes of 110 milk samples that obtained from non-mastitic(healthy) and 110 milk samples obtained from mastitic black and white cows are done in SPSS package program. The regression curves that indicate relations between SCC and EC(Graph-1); initial milking temperature(Graph-2); density (Graph-3); $\mathrm{pH}(\mathrm{Graph}-4)$ of milk samples will be compared in-between two groups (healthy and mastitic) in graph groups below respectivly.

\subsection{SCC \& EC Regression Curves}

From Graph-1, It can be seen that relation between logarithmic transformated SCC and EC values of healthy milk is not significant statistically and reggression coefficient $\left(\mathrm{R}^{2}=0.0316\right)$ is very lowand mean value of EC is $5.809 \pm 0.055$ in healthy group.

It can also be seen that relation between $\operatorname{logSCC}$ and $\mathrm{EC}$ is positive, has a normal distribution and very high $\mathrm{R}^{2}$ value which is 0.89 in mastitic group. Due to high regression coefficient, transformated SCC can be estimated easily with high accuracy by using electrical conductivity in mastitic group. Also it is determined that mean value of EC of the mastitic milks is $7.07 \pm 0.141$ and correlation coefficient $(\mathrm{R}=0.946)$ between SCC and EC is quite high. 
In this study, the mean value of EC in healthy milks which is $5.809 \pm 0.055 \mathrm{mS} / \mathrm{cm}$ corresponds with value of 5.5 $6 \mathrm{mS} / \mathrm{cm}$ reported by Lansbergen et al. (1994) while does not correspond with value of 4-5.5 mS/cm reported by Nielen et al. (1993). Breed, lactation period, milking interval, composition of milk, daily changes, lactation number, oestrus, diseases, nutrition level, udder lobe and factors the other factors related to farm might causes differences. But in mastitic group,the mean value of EC in mastitic group which is $7.07 \pm 0.141$ corresponds with value that reported by Nielen et al. (1992) which is up to $6.0 \mathrm{mS} / \mathrm{cm}$ in case of infection in mammary glands. This is due to the increase in the amount of mineral matter in the milk in case of infection in the mammary glands.

\subsection{SCC \& Initial Milking Temperature Regression Curves}

After tests and analyzes done, the mean value of initial milk temperature is found as $34.387 \pm 0.13{ }^{\circ} \mathrm{C}$. Also a statistically $(\mathrm{P}<0.05)$ low correlation (correlation coefficient $\mathrm{R}=-0.226)$ is found between $\log \mathrm{SCC}$ and Initial milk temperature in healthy cows.

From Graph-2, it can be seen that the relationship between SCC and initial milk temperature is low and Rsquared value is 0.0511 in healthy group.

Mol et al. (2000), in a study that automated detection of oestrus and mastitis in dairy cows; report that temperature rise of milk is detected in cows which are in oestrus period, with mastitis and diseases. It is understood that the milk temperature does not change in healthy cows. The reason of he mean value of initial milk temperature that calculated as $34.387 \pm 0.13^{\circ} \mathrm{C}$ does not correspond with value of reported by Maatje and Rossing (1976) which is $36{ }^{\circ} \mathrm{C}$, might be caused by cold whether conditions during the measurement period (November 2017- April 2018).

From Graph 2, it can be seen that relation between $\operatorname{logSCC}$ and initial milk temperature is positive, has a normal distribution and moderately high of $\mathrm{R}^{2}$ value which is 0.5486 . SCC of cows that known infected with mastitis disease can be estimated since relation between SCC and initial milk temperature $\left(\mathrm{R}^{2}=0.5486\right)$ is moderately high. Also it is determined that mean value of initial milk temperature of the mastitic milks is $33.51 \pm 0.199$ and correlation coefficient $(\mathrm{R}=0.741)$ between SCC and EC is moderately high.

Initial milk temperature in mastitic cows varies and it is thought that inflammation in udder regions where infection developed causes change of milk temperature. Also it is reported that mastitic milks temperature does not show similarity with body temperature.

The mean temperature value of mastitic milk detected in the current study is $33.51 \pm 0.199$, which is not similar to the normal body temperature of $38.6^{\circ} \mathrm{C}$. This difference may be due to the deterioration of the physical structure of the mastitic milks and the climatic factors.

\subsection{SCC \& Milk Density Regression Curves}

After analzyes and tests 110 milk samples that obtained from healthy black and white cows are done, density is found as $1.032 \pm 0.0003 \mathrm{~g} / \mathrm{ml}$. A insignificant relation and a very low low regression coefficient $\left(\mathrm{R}^{2}=0.0007\right)$ are determined.

Ueda (1999), in a study conducted on relationship among milk density, composition and temperature; report that herd milk in Ontario and Alberta was examined for its density at $4{ }^{\circ} \mathrm{C}$ and composition over a whole year, beside that herd milks in Quebec were sent them to determine milk density after keeping samples at $4{ }^{\circ} \mathrm{Cfor} 24$ hours. Ueda (1999), report that examining the seasonal fluctuations of milk density, indicates that the changes in intensity are strongly related to changes in the amount of components, fat, protein and lactose and other solid components are the most important items in the density estimation. It is pointed out that the estimation method of specific weights conversions with oil, protein and lactose and other solid components produces estimates very close to the actual weight / volume values of the experimentally determined equations.

In a study conducted on 23 cows, effect of improving the sanitation priority during milking to milk quality in Indonesia, it was reported that sanitation healing significantly reduced the $\mathrm{pH}$ of the milk and the number of bacteria in the milk, while increasing the milk density and the amount of fat-free dry matter (Suranindyah et al., 2015).

The mean value of density of healthy milks in this study which is $1.032 \pm 0.0003$ corresponds with values of reported by Kaşıkçı et al. (2012) which are 1,031 (CMT +), 1,0297 (CMT++) and 1,029 (CMT+++).

From Graph 3., it can be seen that relation between SCC and density is low and negative however has normal distribution an moderately low of regression $\mathrm{R}^{2}$ which is 0.3445 . Due to moderately low $\mathrm{R}^{2}$, $\mathrm{SCC}$ can be estimated at a certain accuracy level. Also mean value of density is calculated as $1.030 \pm 0.002$ and a moderately high of correlation coefficient $(\mathrm{R}=-0.587)$ is found.

The mean value of density of mastitic milks in this study which is $1.030 \pm 0.002$ corresponds with values of reported by Kaşıçı et al. (2012) which are 1,031 (CMT +), 1,0297 (CMT++) and 1,029 (CMT+++). The reason why the milk density values differ between healthy and mastitic groups is due to the deterioration of the physical structure of the milk. Also changes in milk fat and protein content in mastitic milks have an effect on this situation. 


\subsection{SCC \& pH of The Milk Regression Curves}

In this study, mean value of ph of the healthy milk samples that obtained from 62 black and white cows is found $6.708 \pm 0.012$. From Graph-4, it can be seen that there is a statistically insignificant relation between $\operatorname{logSCC}$ and $\mathrm{pH}$ of healthy milks.

In a study conducted by Tsioulpasve et al (2007), a study of the $\mathrm{pH}$ of individual milk samples, it was noted that the mean $\mathrm{pH}$ value for all individual samples analyzed was $6.63 \pm 0.08$ and there was no significant difference in mean $\mathrm{pH}$ value between early, middle and late lactation periods $(\mathrm{P}>0.05)$. General data and early lactation data indicate normal distributions (Tsioulpas et al., 2007).

It can be said that studies done show a significant correlation between $\mathrm{SCC}$ and $\mathrm{pH}$ with level of the mastitis.

The mean value of $\mathrm{pH}$ of healthy milks that calculated as $6.708 \pm 0.012$ is found higher than values reported by Tsioulpas et al. (2007) and Atasever et al. (2010) which are $6.63 \pm 0.08$ and $6.547 \pm 0.007$ respectively.

From Graph-4, it can be seen that relation between $\operatorname{logSCC}$ and $\mathrm{pH}$ is low and positivie but has normal distribution and low level of regression $\mathrm{R}^{2}$ which is 0.1689 . Due to low level of $\mathrm{R}^{2}, \mathrm{SCC}$ can be estimated at a certain accuracy level. Also mean value of $\mathrm{pH}$ is calculated as $6.88 \pm 0.026$ and a moderately low of correlation coefficient $(\mathrm{R}=-0.411)$ is found.

Harmon (1994), in his study of physiology of mastitis and factors affecting somatic cell counts; report that $\mathrm{pH}$ of the milk can be varied among 6.6- 6.9 even higher values and express that the reason may be the enzymes and blood that mix with milk.

In this study, the mean value of milk $\mathrm{pH}$, which was found to be $6.88 \pm 0.026$ in the mastitis group, is similar to the reported $\mathrm{pH}$ values in the mastitic milks reported by Harmon (1994) between 6.6-6.9 and even higher values. It is thought that the increase in $\mathrm{pH}$ values in mastitic milks is due to the fact that the enzyme and blood involved into milk from diseased tissue (mastitis, etc.) increase the $\mathrm{pH}$ of the milk

\section{Results of Regression Analyzes of Healthy Milks}

According to results of regression anaylzes of healhy group, there was insignificant relation between SCC and EC, initial milk temperature, $\mathrm{pH}$, density. But in mastitic cows, relation is significant and regression $\mathrm{r}^{2}$ is high. Thus by using 4 parameters of milk (EC, temperature, $\mathrm{pH}$, density) subclinical mastitis can be diagnosed. Distributions test were applied to the parameters of healthy group and only temperature features of milk verifies normal distributive. The reason of that situation may be low relationships between releavent parameters and high variation in SCC values.

\section{Results of Regression Analyzes in Mastitic Group}

Findings from regression analzyes of mastitic group show that a high relation is observed among $\operatorname{logSCC}, \mathrm{EC}$ and initial milk temperature while a low relation is observed among $\operatorname{logSCC}, \mathrm{pH}$ and density. Subclinical mastitis can be diagnosed by using one of the parameters (EC, temperature) or both since EC and temperature have a high regression coefficient with $\operatorname{logSCC}$. Relations among $\mathrm{SCC}, \mathrm{pH}$, initial milk temperature and density of infected milks are evaluated and normal distributive is observed among them except SCC while in healthy milks normal distrubitive is observed ampng only initial milk temperature. The reason of that situation may be low relationships between releavent parameters and high variation in SCC values.

\section{Correlations}

Relations between mastitis disease and somatic cell count, electrical conductivity, first milking temperature, milk density and milk pH are given in Table 2; Relations between SCC, which is the most important feature in the diagnosis of mastitis, and all other features are given in Table 3.

From Table 2 and 3, it can be clearly seen that there is a positive correlation between mastitis disease and SCC (somatic cell count), EC and temperature and a negative correlation between SCC and milk density. Relations between mastitis disease and SCC, EC, $\mathrm{pH}$, temperature and density are significant at the 0.01 significiance level. Parameters that High Correlated with Mastitis Disease

It is determined that mastitis disease is high correlated to SCC and ph, correlation coefficients are 0.633 and 0.570 respectively, coefficients are significant at 0.01 significance level.

\section{Parameters that Low Correlated with Mastitis Disease}

Correlation coefficients between mastitis disease and EC, density, temperature are $0.483,-0.241$ and -0.240 respectively that significant at 0.01 significance level.

\section{Correlations in Healthy Group}

In healthy group, only a high correlation $(\mathrm{R}=0.524)$ was found between $\mathrm{EC}$ and $\mathrm{pH}$ which is statistacally significant at 0.01 significiance level.

The correlation coefficients of EC, density, temperature and $\mathrm{pH}$ with $\mathrm{SCC}$ which is the most significant parameters to diagnose mastitis are $0.178,-0.027,0.203$ respectively and statistically significant at 0.01 significance level.

\section{Correlations in Mastitic Group}

A high correlation that statistically significant at 0.01 significiancy level was found between SCC (the most significant parameter to detect mastitis) and all other parameters except $\mathrm{pH}$. The correlation between $\mathrm{SCC}$ and $\mathrm{pH}$ was low and correlation coefficient $\mathrm{R}=0.411$. 
It is determined that in mastitic group relations of SCC with all other paramaters are very high or high while in healty group relations between all parameters are insignificant or low. In addition, when parameters were examined between mastitic and healthy groups; it was found that SCC was correlated positively with $\mathrm{EC}$ and $\mathrm{pH}$ while negatively with density in both goups, positively with initial milk temperature in mastitic group but negatively in healthy group. Also it is determined that the correlation of SCC with all other parameters in mastitic group is higher than healthy group.

\section{Conclussions And Suggestions}

In this study, the relationship between SCC, electrical conductivity, initial milking temperature, $\mathrm{pH}$ and density were investigated in the presence of subclinical mastitis in milk

There wasn't any statistically significant relation between the relevant features in the healthy group.

It is understood that there is a very important relation in mastitic milks and that the regression coefficients are quite high.

All of the features studied in the current study were found to be statistically significant in relation to mastitis disease at the 0.01 level of significance.

The correlation coefficient between conductivity, temperature, density and $\mathrm{pH}$ characteristics with SCC, which is the most important indicator in determining mastitis, was determined as $0.887,0.246,-0.356,0.594$ respectively and it was found to be significant at 0.01 significance level.

When this study was examined as a whole, the milk samples taken from cows with mastitis group mean values of SCC, EC, density, initial milk temperature and $\mathrm{pH}$ are 1066.86 $\pm 83.537,7.07 \pm 0.114,1.030 \pm 0.002,33.51 \pm$ $0.199,6,88 \pm 0,026$, respectively; in healthy group, these values were found to be SCC as $75,736 \pm 4,875$, electrical conductivity as 5,809 $\pm 0,055$, density as $1,032 \pm 0,003$, initial milk temperature as $34,387 \pm 0,13$ and $\mathrm{pH}$ as 6,708 $\pm 0,012$. In addition, when parameters were examined between mastitic and healthy groups; while it was found that SCC had been positively correlated with $\mathrm{EC}$ and $\mathrm{pH}$, negatively with density in both goups; positively correlated with initial milking temperature in mastitic group but negatively in healthy group.

It is determined that mastititis disease is highly correlated with $\mathrm{SCC}$ and $\mathrm{pH}$ of milks (correlation coefficients respectively $\mathrm{r}=0.663 ; \mathrm{r}=0.570$ ) in current study conducted in order to determine the relationships between milk $\mathrm{SCC}$, electrical conductivity, $\mathrm{pH}$, initial milking temperature and milk density in cows with and without mastitis. There was not statistically significant relationship between SCC and other parameters in the healthy group while it is determined that there is a very significant relationship between SCC and other features in the mastitic group. As a conclusion, it has been evaluated that the use of milk SCC, electrical conductivity, $\mathrm{pH}$, initial milking temperature and milk density as an indicator of mastitis will give an effective resultant.

\section{References}

Akgül, A., 2003. Tıbbi Araştırmalarda İstatistiksel Analiz Teknikleri “Spss Uygulamaları” (2. Baskı). Emek Ofset Ltd. Şti., Ankara.

Alpar, R., 2003. Uygulamalı Çok Değişkenli İstatistiksel Yöntemlere Giriş 1 (2.Baskı). Nobel Yayın Dağıtım Ltd. Şti . Ankara.

Altman, D., G., 1992. Practical Statistics for Medical Research. Chapman and Hall, London.

Atasever, S., Erdem, H., 2008. Süt Sığırlarında Mastitis İle Sütün Elektriksel İletkenliği Arasındaki İlişkiler. Omü Zir. Fak. Dergisi, 23, 2, 131-136.

2010. Relationship Between Somatic Cell Count and pH. Journal of Veterinary Advances, Samsun Turkiye,9, 11, 1575-1577

Dawson,-Saunders B., Trapp, R., G., 1990. Basic and Clinical Biostatistics. Appleton \& Lange.

Draper, N.R. Smith H., 1981. Applied Regression Analysis (SecondEdition). John Wiley \& Sons, Inc.

Fernando, R. S., Spahr, S. L. ve Jaster, E. H., 1985. Comparison Of Electrical Conductivity Of Milk With Other İndirect Methods For Detection Of Subclinical Mastitis. Journal of Dairy Science, 68(2), 449-56.

Gil, Z. 1988. Milk Temperature Fluctuations During Milking in Cows with Subclinical Mastitis. Livestock Production Science. 20(3), 223-231.

Göncü, S., Özkütük, K., 1999. Değişik Yaşlı Süt İneklerinden Alınan Süt Örneklerinin Somatik Hücre Sayısı Yönünden Değerlendirilmesi. Uluslararası Hayvanc1lık '99 Kongresi 21-24 Eylül, İzmir, 111-118.

, 2002. Adana Entansif Süt Sı ̆̆ırcılığı İşletmelerinde Yetiştirilen Saf ve Melez Siyah Alaca İnek Sütlerinde Somatik Hücre Sayısına Etki Eden Faktörler ve Mastitis ile İlişkisi, 43(2), 44-53.

2017. Süt Somatik Hücre Sayımı ve Süt sığırcılığında Önemi. http://www.muratgorgulu.com.tr/altekran.asp?id=129

Gradinaru, A. C., Creanga, S. ve Solcan, G., 2015. Milk - a review on its synthesis, composition, and quality $\begin{array}{llll}\text { assurance in industry. HVM Bioflux, } & \text { 7(3), }\end{array}$ http://search.ebscohost.com/login.aspx?direct=true\&db=lah\&AN=20153313380\&site=ehostlive\%5Cnhttp://www.cabi.org/cabdirect/showpdf.aspx?PAN=http://www.cabi.org/cabdirect/showpdf.aspx? 
PAN=20153313380\%5Cnhttp://www.hvm.bioflux.com.ro/docs/2015.a173-177.pdf\%5Cnemail

Harmon, R. J., 1994. Physiology of Mastitis and Factors Affecting Somatic Cell Counts. Journal of Dairy Science, 77(7), 2103-2112.

Hortet, P., Seegers, H., 1998. Loss in Milk Yield And Related Composition Changes Resulting from Clinical Mastitis in Dairy Cows. Preventive Veterinary Medicine, 37: (1-4), 1-20

Kaşıkçı, G., ve ark, 2012. Relations Between Electrical Conductivity, Somatic Cell Count, California Mastitis Test and Some Quality Parameters in The Diagnosis of Subclinical Mastitis in Dairy Cows. Turk. J. Vet. Anim. Sci.; 36(1), 49-55.

Kayaalp, T., Çankaya, S., 2013. İstatistik. ÇÜ Ziraat Fakültesi Ofset Atölyesi, Adana, 258, 158s. , 2017. Araştırma ve Deneme Metodları. ÇÜ Ziraat Fakültesi Ofset Atölyesi, Adana, 282, 208.

Lansbergen, L.M.T.E., Nielen M, Lam TJGM, et al., 1994. Evaluation of a Prototypeon-Line Electrical Conductivity System for Detection of Subclinical Mastitis. J Dairy Sci; 77: 4, 1132-1140.

Maatje, K. \& Rossing, W., 1976. Detecting Oestrus by Measuring Milk Temperature of Dairy Cows During Milking. Livestock Production Sciences, 3, 85-89

1992. The Efficacy of in-Line Measurement of Quarter Milk Electrical Conductivity, Milk Yield and Milk Temperature for The Detection of Clinical and Subclinical Mastitis. Livestock Production Science, 30(3), 239-249.

Mol, R. M. de., 2000. Automated Detection of Oestrus and Mastitis in Dairy Cows. Automated Detection of Oestrus And Mastitis in Dairy Cows. 126.

Nielen, M., et al., 1992. Electrical Conductivity of Milk: Measurement, Modifiers, and Meta Analysis of Mastitis Detection Performance. J. Dairy Sci. 75: 606-614.

1993. Relations Between On-Line Electrical Conductivity and Daily Milk Production on a Low Somatic Cell Count Farm. Journal of Dairy Science, 76(9), 2589-2596.

Shook, G. E. Ve ark., 1980. An Optimum Transformation for Somatic Cell Concentration in Milk. Journal of Dairy Science, Wisconsin, 63, 3, 487-490.

Špauskas, V., Klimiene, I. And Matusevičius, A., 2006. A Comparison of Indirect Methods For Diagnosis of Subclinical Mastitis in Lactating Dairy Cows. Vet. Arhiv. 76 (2): 101- 109.

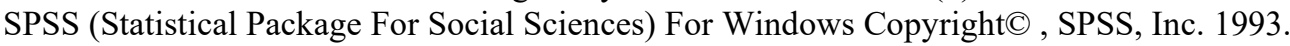

Suranindyah, Y., ve ark, 2015. The Effect of Improving Sanitation Prior to Milking on Milk Quality of Dairy Cow in Farmer Group. Procedia Food Science, 3, 150 - 155

Tsioulpas, A., Lewis M J * and Grandison, A. S., 2007. A Study of the pH of Individual Milk Samples. J Dairy Res., 74(2):167-73.

TÜIK, 2016. Hayvansal Üretim İstatistikleri. 2s. www.tuik.gov.tr/PdfGetir.do?id=24655

Ueda, A., 1999. Relationship Among Milk Density, Composition and Temperature. 129.

Table 1. Mean and standart deviation of SCC, EC, initial milk temeperature, density and $\mathrm{pH}$ of milks with and without mastititis.

\begin{tabular}{|l|l|l|l|l|l|l|l|l|l|l|l|l|}
\hline & \multicolumn{4}{|l|}{ Mastitic Group } & \multicolumn{3}{l|}{ Healthy Group } & \multirow{2}{*}{ Overall Mean } & \multirow{2}{*}{ Total N } & Sig. \\
\hline & $\mathrm{n}$ & $\min$ & $\max$ & $\operatorname{mean}$ & $\mathrm{n}$ & $\min$ & $\max$ & mean & & & \\
\hline SCC & 113 & 215 & 4588 & $1066.86 \pm 83.537$ & 106 & 6 & 196 & $75.736 \pm 4.875$ & $571.297 \pm 53.909$ & 219 & $\mathrm{P}<0.01^{*}$ \\
\hline EC & 113 & 3.9 & 11.15 & $7.07 \pm 0.141$ & 106 & 3.97 & 7.75 & $5.809 \pm 0.055$ & $6.459 \pm 0.088$ & 219 & $\mathrm{P}<0.01$ \\
\hline Density & 113 & 1.027 & 1.038 & $1.030 \pm 0.0002$ & 106 & 1.027 & 1.036 & $1.032 \pm 0.0003$ & $1.031 \pm 0.0002$ & 218 & $\mathrm{P}<0.01$ \\
\hline Temperature & 106 & 25.7 & 37.5 & $33.51 \pm 0.199$ & 106 & 30.2 & 37.2 & $34.387 \pm 0.13$ & $33.937 \pm 0.123$ & 212 & $\mathrm{P}<0.01$ \\
\hline pH & 38 & 6.57 & 7.24 & $6.88 \pm 0.026$ & 62 & 6.55 & 7.03 & $6.708 \pm 0.012$ & $6.773 \pm 0.015$ & 100 & $\mathrm{P}<0.01$ \\
\hline
\end{tabular}

Difference between means are statistically significance a level of 0.01 .

* Since SCC values are not show up a normal distribituve, after logarithmic transformation is applied to SCC values, significance is calculated. But min-max and mean values of SCC is calcuated over actual data, not transformed data.

Difference between means are statistically significant at 0.01 significance level.

*Since SCC values are not show up a normal distribituve, after logarithmic transformation is applied to SCC values, significance is calculated. But min-max and mean values of SCC is calcuated over actual data, not transformed data. 

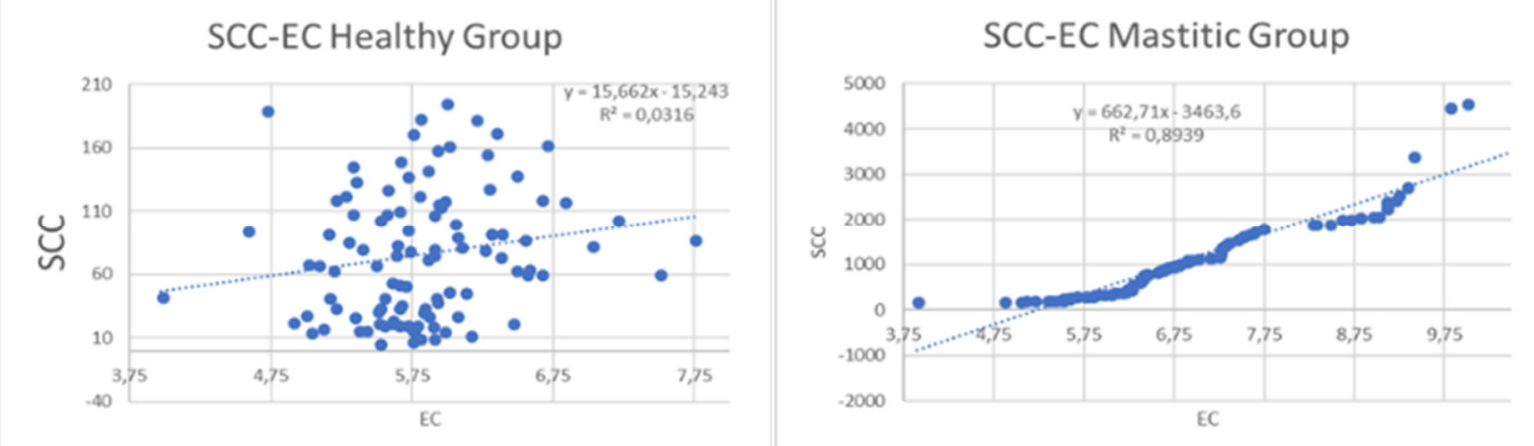

Figure 1. Regression curve of SCC \& EC in mastitic and healthy groups
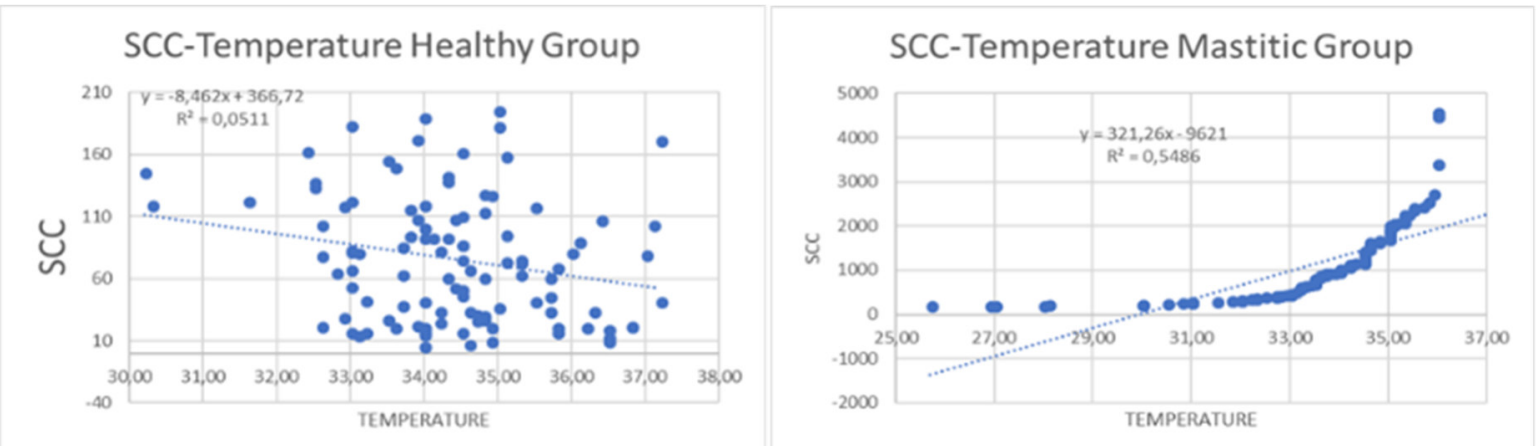

Figure 2. Regression curves of SCC \& Temperature in mastitic and healthy groups
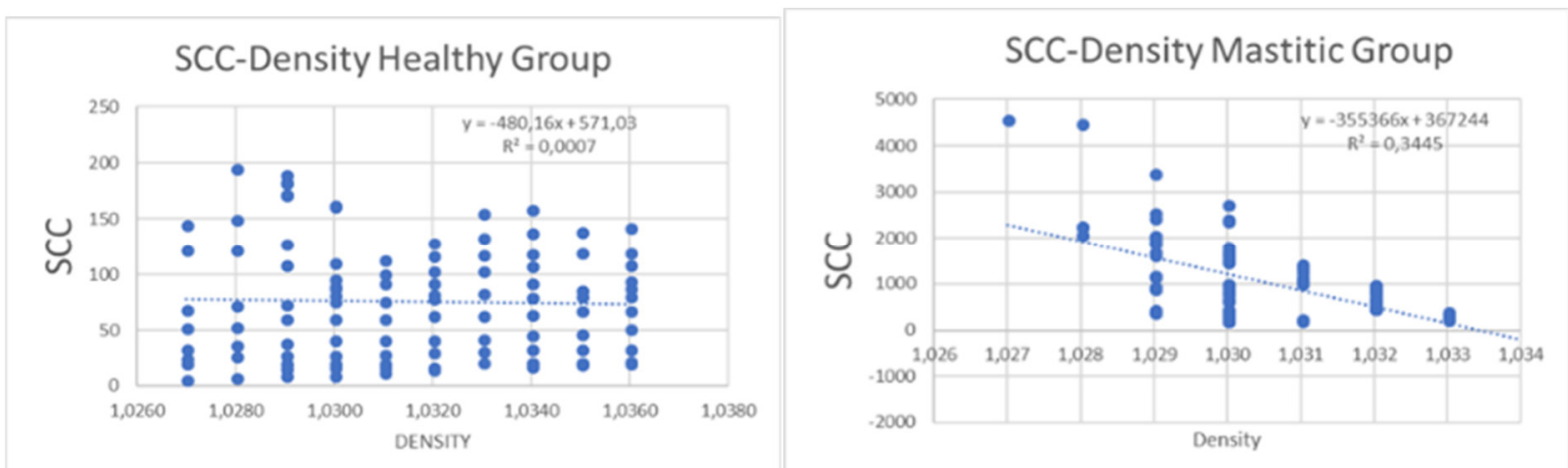

Figure 3. Regression Curves of SCC \& Density in healthy and mastitic groups
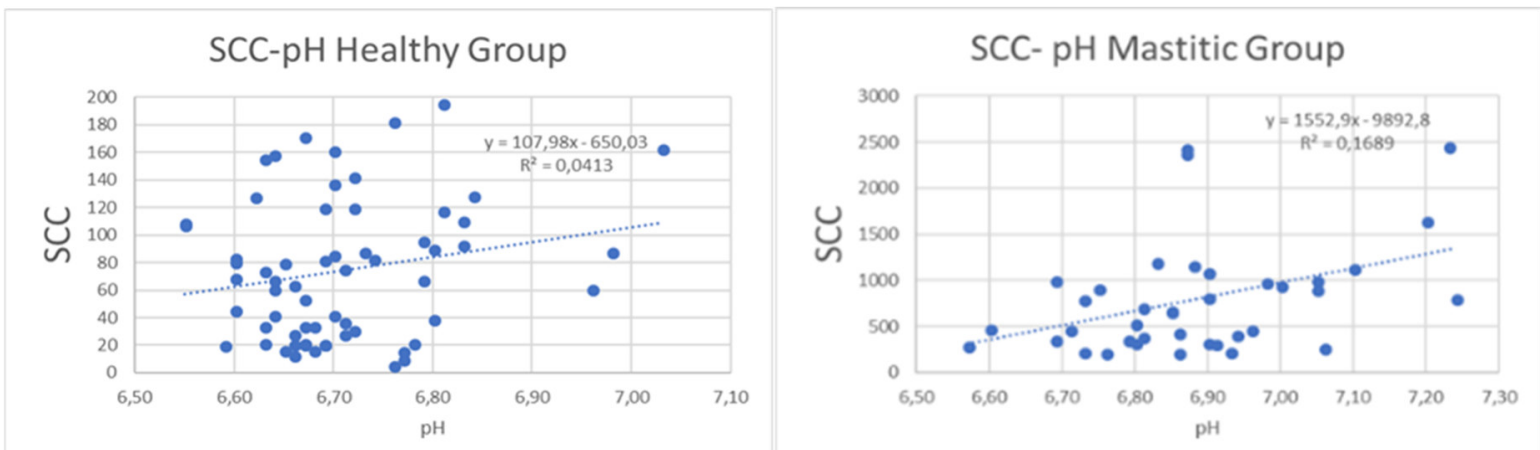

Figure 4. Regression Curves of SCC \& Milk pH in healthy and mastitic groups 
Table 2. Correlations between parameters

\begin{tabular}{|l|l|l|l|l|l|l|}
\hline Parameters & SCC & EC & Density & Temperature & $\mathrm{pH}$ & Mastitis Disease \\
\hline SCC & 1 & $.887^{* *}$ & $-.356^{* *}$ & $.246^{* *}$ & $.594^{* *}$ &, $633^{* *}$ \\
\hline EC &, $887^{* *}$ & 1 &,$- 276^{* *}$ &, $476^{* *}$ &, $502^{* *}$ &, $483^{* *}$ \\
\hline Density &,$- 356^{* *}$ &,$- 276^{* *}$ & 1 &,- 061 &,$- 250^{*}$ &,$- 241^{* *}$ \\
\hline Temperature &, $246^{* *}$ &, $476^{* *}$ &,- 061 & 1 &,$- 214 *$ &,$- 240^{* *}$ \\
\hline $\mathrm{pH}$ &, $594 * *$ &, $502 * *$ &,$- 250^{*}$ &,$- 214^{*}$ & 1 &, $570^{* *}$ \\
\hline Mastitis Disease &, $633^{* *}$ &, $483^{* *}$ &,$- 241^{* *}$ &,$- 240^{* *}$ &, $570 * *$ & 1 \\
\hline
\end{tabular}

**. Significant at 0.01 significance level (2-tailed).

*. Significant at 0.05 significance level (2-tailed).

Table 3. Relationships between parameters of mastitic and healthy milks

\begin{tabular}{|c|c|c|c|c|c|c|c|c|c|c|}
\hline & \multicolumn{2}{|c|}{ SCC } & \multicolumn{2}{|c|}{ EC } & \multicolumn{2}{|c|}{ Density } & \multicolumn{2}{|c|}{ Temperature } & \multicolumn{2}{|c|}{$\mathrm{pH}$} \\
\hline & $\begin{array}{l}\text { Health } \\
\mathrm{y}\end{array}$ & $\begin{array}{l}\text { Mastiti } \\
\text { c }\end{array}$ & $\begin{array}{l}\text { Health } \\
\mathrm{y}\end{array}$ & $\begin{array}{l}\text { Mastiti } \\
\text { c }\end{array}$ & $\begin{array}{l}\text { Health } \\
\mathrm{y}\end{array}$ & $\begin{array}{l}\text { Mastiti } \\
\text { c }\end{array}$ & $\begin{array}{l}\text { Health } \\
\mathrm{y}\end{array}$ & \begin{tabular}{|l} 
Mastiti \\
c
\end{tabular} & $\begin{array}{l}\text { Health } \\
\mathrm{y}\end{array}$ & $\begin{array}{l}\text { Mastiti } \\
\text { c }\end{array}$ \\
\hline SCC & 1 & 1 &, 178 & ,946** &,- 027 &,$- 587 * *$ &,$- 226^{*}$ &, $741 * *$ &, 203 &, $411^{*}$ \\
\hline $\mathrm{EC}$ & , 178 & 946** & 1 & 1 &,- 001 &,$- 391 * *$ &, 158 &, $852 * *$ &, $524 * *$ &, $352 *$ \\
\hline Density &,- 027 &,$- 587 * *$ &,- 001 &,$- 391 * *$ & 1 & 1 &, 035 &,$- 325 * *$ &,- 159 &,- 261 \\
\hline $\begin{array}{l}\text { Temperatur } \\
\text { e }\end{array}$ &,$- 226^{*}$ & ,741** &, 158 &, $852 * *$ &, 035 &,$- 325 * *$ & 1 & 1 &,- 179 & ,268 \\
\hline $\mathrm{pH}$ & 203 &, $411^{*}$ &, $524 * *$ & ,352* &,- 159 &,- 261 &,- 179 & ,268 & 1 & 1 \\
\hline
\end{tabular}

**. Significant at 0.01 significance level (2-tailed).

*. Significant at 0.05 significance level (2-tailed). 